\title{
5. 凝固・線溶と臨床検査
}

The clinical laboratory tests of blood coagulation and fibrinolysis

\section{Point}

(1)近年，生体内凝固反応という新しい考え方が導入され，生体内では第 XII 因 子活性化から始まる内因系凝固の関与が少ない点に留意する必要がある.

(2)トロンボテストは PIVKA の影響を含めた凝固活性を反映し，測定時に凝固 第 V 因子が補充されているため，第 $\mathrm{V}$ 因子欠損では低下しない. ヘパプラス チンテストは，PIVKA に対する感受性が低く，肝臓における凝固因子の産生 能を反映する.

(3)アンチトロンビン（AT）はヘパリン存在下で約 1000 倍にトロンビン活性阻 害速度が加速され（ヘパリンコファクター活性），臨床検査で示される AT 活 性值はこのヘパリンコファクター活性を示している.

(4)プロテインS（PS）は，ワルファリン投与により低下するため，日本人に多 く存在する PS 欠損症診断には，ワルファリン治療前に PS 検査を行う必要 がある.

(5)プラスミノゲンアクチベーターインヒビター（PAI-1）は，感染症（とくに 敗血症) で高值を示し，多蔵器障害予後判定に有用である.

\section{1.はじめに}

凝固・線溶反応は，凝固と抗凝固反応およ び線溶と抗線溶反応のバランスが相互に作用し ながら成立する。それぞれのバランスが破綻す ると, 出血性疾患あるいは血栓症を発症する. そこで, 凝固・線溶系検査は, 出血および血栓 性疾患の病因や病態把握, 治療効果を判断する ために必須となる，凝固・線溶はお互いに影響
する連続反応であるが, 本稿では便宜上, 凝固 反応系検査, 線溶系検査に分けて概説する.

\section{2. 試験管内凝固反応と生体内凝固反応}

現在まで, 凝固反応はin vitroの精巧な実 験により構築された cascade 説ならびに water sequence 説が基本となっている. 凝固因子が 連続した酵素反応により反応が増幅され, トロ

*富山大学大学院医学薬学研究部臨床分子病態検査学講座〔 $\bar{T}$ 930-0194 富山市杉谷 2630〕

Clinical Laboratory and Molecular Pathology, University of Toyama〔2630 Sugitani Toyama 930-0194, Japan〕

Tel: 076-434-7735 Fax: 076-434-4501 e-mail: kitajima@med.u-toyama.ac.jp 


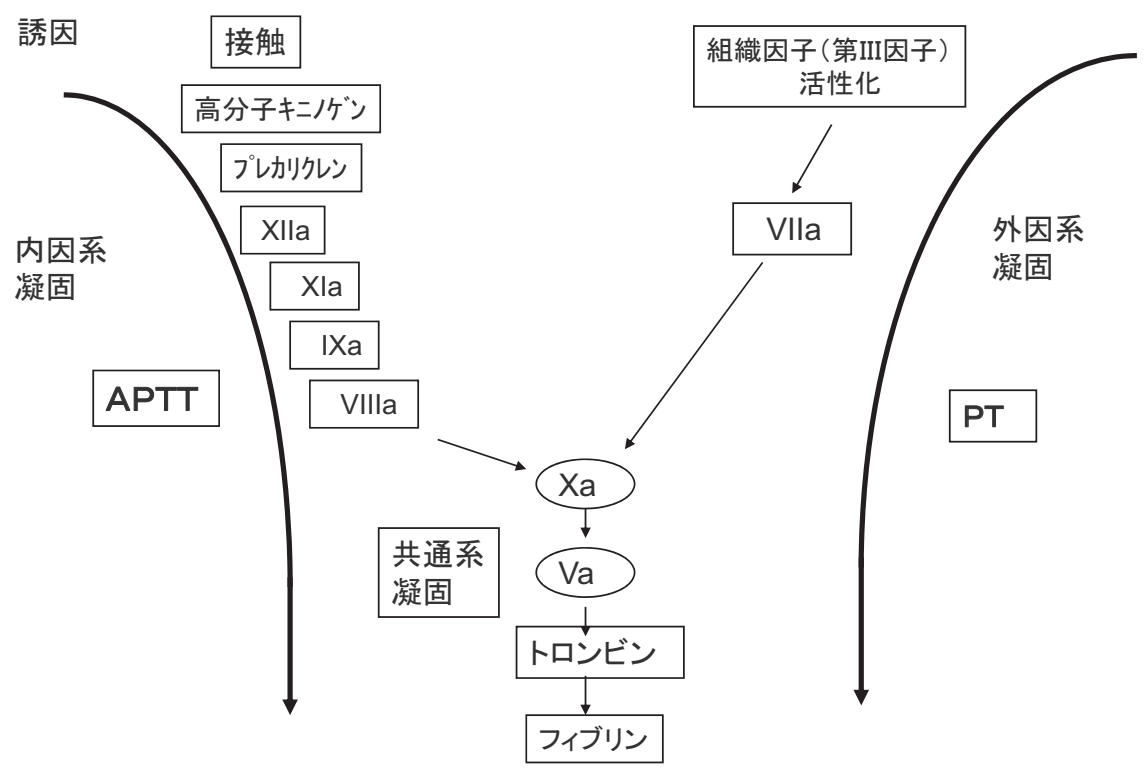

図 1 試験管内の凝固反応（Cascade 説） 試験管内凝固反応では，外因系（PT）はトロンボプラスチン, 内因系 (APTT) はセファリンによって開始される.

ンビンの生成により，可溶性フィブリノゲンを 不溶性フィブリンに変換する説得力のある説で ある。この説を基盤に PT, APTT が臨床利用 されている(図 1)。しかし，臨床的に，血友 病は APTT が著明に延長するものの PT は基準 範囲内にある。そして，外因系凝固は共通系と して第 X因子活性化反応に合流するにもかか わらず出血症状を呈する。また，先天性第VII因 子欠乏症の中には内因系凝固反応に異常がない 試験管内凝固反応系では説明が困難な臨床例が 存在する ${ }^{1)}$.

そこで, 近年, 生体内凝固反応経路という新 しい考え方が導入されている ${ }^{2)}$. 生体内では, 血管内皮細胞の障害や活性により露出した組織 因子が血液中に出現することにより凝固反応が 開始される。組織因子は循環血液中に存在する 活性第 VII 因子と複合体を形成し，第 IX 因子 の活性化を介した第 X 因子活性化経路が生体 内凝固の主な反応系である。従って，生体内で は，第 XII 因子活性化から始まる内因系凝固の 関与は少ないことが特徵である（図 2 ).

\section{3. 凝固系検査}

（1）活性化凝固時間（ACT， activated clotting time)

ベットサイドで簡易に実施できる採血した血 液が凝固するまでの時間を測定する検査であ る。この検査は凝固反応に必要なリン脂質を供 給するために，士分な血小板数が必要である. 測定誤差や個人差が大きく，体外循環導入時に ヘパリン効果判定や終了時のプロタミンによる ヘパリン中和能の判定に臨床的有用性がある. （基準值：90-120 秒)

\section{（2）プロトロンビン時間（PT）}

Cascade 説に基く組織因子で開始される外因 系および共通系についての検査である，先天性 凝固因子欠損・異常症, 肝機能障害, ビタミン $\mathrm{K}$ 欠乏症（凝固第 II，VII，X 因子，DIC，凝固 阻害因子（ループスアンチコアグラント，凝固因 子インヒビター等)，ヘパリン投与で延長する.

$\mathrm{PT}$ 延長の国際的基準として, INR-PT (international normalized ratio-PT) を活用する. 


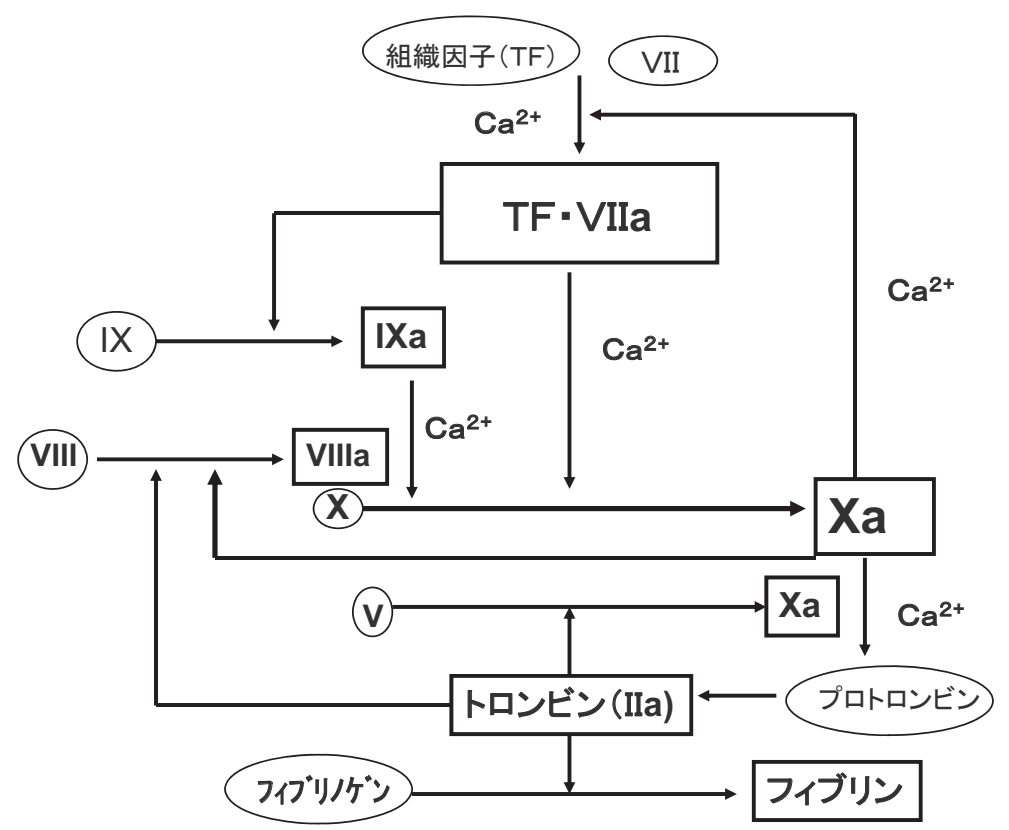

図 2 生体内凝固反応経路 (Williams 改変)

組織因子により開始され，VII 因子による第 IX 因子を介した第 X 因子活性 経路が主体である.内因系反応は重要な役割を担っていない.

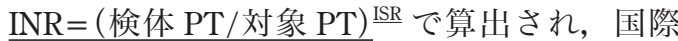
感度指標 ISR は各試薬のロットごと使用機器 ごとに個別に設定されている. INR-PT 值は, 経口抗凝固療法の治療域は, 肺血栓塞栓症, 深 部静脈血栓症では $1.5 \sim 2.5$, 人工弁置換術患者 は $2.0 〜 3.0$ で，4.0を超えると出血の危険が高 いと推定できる.

\section{（3）活性化部分トロンボプラスチン時間} (APTT)

Cascade 説に基く凝固内因系および共通経路 を調べる検査である，基準は $30 \sim 40$ 秒である が, 試薬の種類により測定值に幅が生じるため, 一般に，正常対照との差が 10 秒以内を正常と 判断する。延長が認められた場合，凝固因子の 低下と凝固阻害因子の存在が考えられる。PT 延長・APTT 延長時はフィブリノゲン，プロト ロンビン，第 $\mathrm{V}$ 因子，第 $\mathrm{X}$ 因子，複合因子欠 損, PT 延長・APTT 正常では第 VII 因子欠乏, PT 正常・APTT 延長時には，第 VIII 因子，第 IX 因子，第 XI 因子，第 XII 因子，フォンビレ
ブラント因子，高分子キニノゲン，プレカリク レイン欠損を疑う。

\section{（4）トンボテストとヘパプラスチンテスト}

トロンボテストは protein induced by vitamin

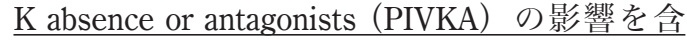
めた凝固活性を反映し，ワルファリンなどによ る抗凝固薬療法のモニターに用いられる。測定 時にバリウム吸着ウシ血漿し，第 V 因子が補 充されるため，第 $\mathrm{V}$ 因子欠損では低下しない. ヘパプラスチンテストは, PIVKA に対する感 受性が低く，肝臓における凝固因子の産生能を 反映するため, 肝臓の蛋白合成能の評価にも利 用できる.また，トロンボテストとへパプラスチ ンテストの差から, PIVKA 量の推定ができる.

\section{4. 抗凝固系検査}

生体内では, 凝固反応の活性化を適切に抑制 する機構を有している。この機構が低下すると 血栓症が生じやすくなる。そのため，抗凝固機 


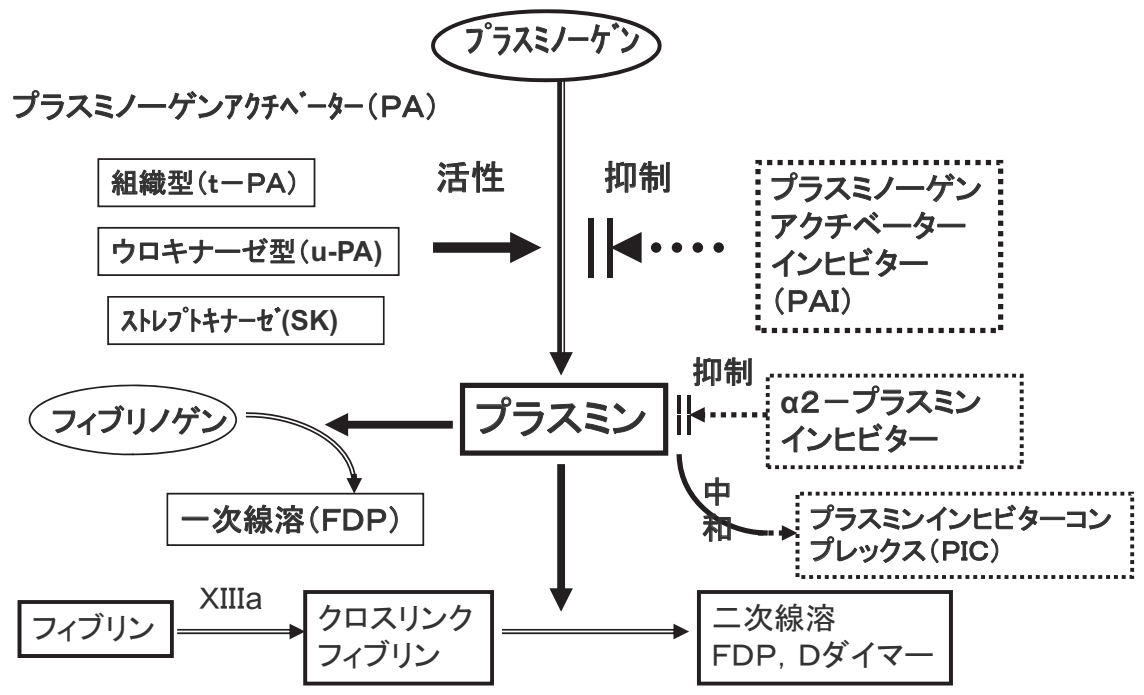

図 3 線溶機構に関わる因子と臨床検査

構を検査することは，血栓症の病因・診断・予 後判定に重要な情報を得ることができる.

\section{（1） アンチトロンビン（AT）}

アンチトロンビンはトロンビンと $1: 1$ の割 合で複合体を形成し，トロンビン作用を不活で きる生理阻害物質である。AT はトロンビン以 外に凝固第 II, IX，X，XI も阻害する。 AT は ヘパリン存在下で約 1000 倍にトロンビン活性 化阻害速度が加速され（ヘパリンコファクター 活性), 臨床検査で測定されるAT 活性值はこ のヘパリンコファクター活性である。先天性ア ンチロンビン欠損症は 500 人に 1 人という頻度 のため，血栓症病因の重要な疾患であることを 念頭において診療する必要がある.

(2) プロテイン C (PC)

ビタミン $\mathrm{K}$ 依存性蛋白質で，生成された卜 ロンビンと血管内皮細胞上のトロンボモジュリ ンの複合体によって活性化され，プロテイン $\mathrm{S}$ （PS）を補酵素として活性化第 $\mathrm{V}$ 因子と活性化 第 VIII 因子を選択的に不活性化する。PC は第 VII 因子と同様，その半減期が非常に短いため, ワルファリンを投与すると，プロトロンビンな ぞの凝固因子低下による抗凝固作用発現以前に $\mathrm{PC}$ が低下する.このため, ワルファリン投与
開始時に，一時的に血栓傾向が高くなる可能性 が生ずることに注意すべきである。

(3) プロテイン S（PS）

ビタミン K 依存性蛋白質の 1 つで PC の補酵 素として作用する。血漿中 PS は約 $60 \%$ が補体 制御因子 C4b 結合蛋白質と結合し, 活性化 PC の補酵素活性を有しない。残りの $40 \%$ に補酵 素活性があり，さらに PS は血小板や血管内皮 細胞の膜表面にも存在している.PS 欠損症は 日本人において $0.4-2 \%$ も存在し, 欧米人に比 し高頻度である点と，ワルファリン投与により PS がさらに低下するため, 深部静脈血栓症の 重要な原因精査でPSを検査する際は, ワルファ リン投与前に実施することが重要である.

\section{5. 線溶系検査}

プラスミノーゲンアクチベーターによりプラ スミンが生成される過程が線溶反応の開始点で ある。プラスミンはフィブリノゲンやフィブリ ンに作用し，種々の分解産物を生成する。プラ スミンが主にフィブリノゲンを分解する段階ま でを 1 次線溶といい, FDPが生成される.さ らに凝固反応が進み，トロンビンが作用して 
SFMC が生成され，さらにXIII 因子で架橋さ れた安定化フィブリンが形成されると，生体は プラスミンをさらに活性化し, 安定化フィブ リンを分解する。この段階を二次線溶といい, FDP と D ダイマーが生成される。生体内では FDP D ダイマーは単一な分子ではなく, 様々 な分解過程の生成物で多様性に富んでいること に留意すべきである。また，線溶系においても 血中に抑制物質が存在し，プラスミンは $\alpha 2$ プ ラスミンインヒビターにより中和され，プラス ミン・ $\alpha 2$ プラスミンインヒビター複合体 (PIC) が生成される $(\text { 図 3 })^{3)}$.

\section{(1) プラスミノゲン}

線溶反応の主役を演じるプラスミンは，その 前駆体であるプラスミンが組織プラスミノゲン アクチベータ（t-PA）によって活性化され生成 される。日本人では，先天性プラスミノゲン異 常症の頻度が高く，へテロ接合体の症例は健常 者の約 $3 \%$ に認められる。しかし，へテロ例で は，血栓症の頻度は有意に高くない。また，近 年，t-PA 治療が心筋梗塞，脳梗塞で実施され るようになったが，t-PA 投与により，プラス ミノゲンはプラスミンにより活性化され，消費 により減少する。

\section{（2）フィブリン分解産物（FDP）}

抗フィブリノゲン抗体を用いたラッテクス凝 集反応法で測定される total-FDP と抗 FDP-E 抗体を用いた測定系が存在する，従って，検査 に用いる抗体により認識される FDP が異なる ことに留意すべきである。また，Total-FDP, FDP-E は，測定原理上フィブリノゲンと交差 反応を示すので，検体からフィブリノゲンを完 全に除去する必要がある。さらにへパリン投与 時の検体では十分に凝固していない可能性もあ る。最近，フィブリノゲン分解産物を特異的に 認識するモノクローナル抗体を用いた特異的測 定法が利用できるようになっている。

(3) D ダイマー

抗 DDモノクローナル抗体で測定される
FDP がD ダイマーである.この抗 DD 抗体は, フィブリノゲンと反応しないため検体として は，血漿，血清どちらも用いることができる． $\mathrm{D}$ ダイマーは測定試薬や測定法の違いから基準 範囲が異なることに注意する必要がある。（ラ テックス凝集法 1.0 $0.2 \mu \mathrm{g} / \mathrm{ml}$, ラテックス免 疫比濁法 $<1.0 \mu \mathrm{g} / \mathrm{ml}$ ) 肺血栓塞栓症の診断に 有用性が認められている。

\section{(4) プラスミン・ $\alpha 2$ プラスミンインヒビター}

\section{複合体（PIC）}

$\alpha 2$ プラスミンインヒビターは即時的にプラ スミンと結合して PICを生成する.PICは血 中半減期が約 6 時間で網内系で処理されるた め, 比較的近い時間のプラスミン活性を評価で きる．基準範囲は $0.8 \mathrm{mg} / \mathrm{ml}$ 未満で，軽度〜中 等度線溶立進状態では $0.8 \sim 3.2 \mathrm{mg} / \mathrm{ml}$ 高度線 溶无進状態になると $3.2 \mathrm{mg} / \mathrm{ml}$ を超える值を示 す.

（5）プラスミノゲンアクチベーターインヒ ビター (PAI-1)

PAI-1 はプラスミン生成を抑制し線溶系反応 を制御しているため，その上昇は血栓溶解能の 低下を示唆する。また。感染症（特に敗血症） で高值を示し，病態を反映するため多臓器障害 の予後の指標として注目されている．PAI-1 検 査で注意すべき事項として，血小板にも存在し， 血小板活性化に伴い血液中に放出されるため, 採血時のトラブルや採血後室温で検体を放置す ると高值を示す。また，日内変動が知られてお り，早朝が最も高く，夜間に低值を示すことも 知っておく必要がある.

\section{文献}

1）高宮脩: 凝固検査成績と臨床症状との乘離一新しい凝 固機序の考え方一. 日本検査血液学会雑誌 9(1)：60-68, 2008.

2) Hoffman $\mathrm{H}$ : Remodeling the blood coagulation cascade. J Thromb Haemost $16: 17-20,2003$

3）山口桂司, 北島勲 : FDP, FgDP, FDP-E. 血栓症検査ガイド ブック.血栓と循環 12(4) : 101-104, 2004. 